\title{
Contact-induced spread of the rare Type 5 clitic
}

\author{
Johanna Nichols, UC Berkeley (johanna@berkeley.edu) \\ David A. Peterson, Dartmouth College (david.a.peterson@dartmouth.edu)
}

\section{LSA Annual Meeting, 7 January 2010, Baltimore}

\section{Type 5 clitics in Ingush and nearby}

Peterson 2001 shows that the Ingush (Nakh-Daghestanian; Caucasus) chaining particle $=^{\prime} a$ is a Type 5 clitic in the typology of Klavans 1985: it is positioned relative to the final word in its domain, precedes that word, and is enclitic to the word before that. The clitic is obligatory in a chaining construction analogous to what Crowley 2002 calls core serialization: a nonembedded converb clause which obligatorily has conjunct tense and mood scope (in the terms of Bickel's multivariate typology) and obligatorily shares an argument with the final clause. In Ingush core chaining the converb clause is verb-final and the main clause verb-initial. The host of the clitic chaining particle is the absolutive argument if there is one; lacking that, the preverb; lacking that, a non-absolutive object; lacking that, a preposed reduplication of the verb root whose only function is to host the clitic. This chaining construction is ubiquitous in all genres. The shared argument is usually the subject, but the usage of the oldest speakers suggests that there was formerly syntactic ergativity here, with shared S/O. An identical construction with the cognate particle is found in closely related Chechen (Conathan \& Good 2000). The same (or a homophonous) clitic functions as an NP coordinating conjunction, where it is an ordinary enclitic to the word in its scope. Ingush examples are (1)-(6).

(1) Absolutive P as host:

\begin{tabular}{|c|c|c|c|c|}
\hline $\begin{array}{l}\text { Peat'mat-aa } \\
\text { P-DAT }\end{array}$ & $\begin{array}{l}\text { axcha }=^{\prime} a \\
\text { money }=\&\end{array}$ & $\begin{array}{l}\text { danna, } \\
\text { D.give.CVant }\end{array}$ & $\begin{array}{l}\text { aara-veal-ar } \\
\text { out-V.go-WP }\end{array}$ & $\begin{array}{l}\text { Muusaa } \\
\text { Musa }\end{array}$ \\
\hline
\end{tabular}

(2) First bipartite stem element as host:

$\begin{array}{lllll}\text { Shok }=\text { 'a } & \text { tiexaa } & \text { shljeapa } & \text { dwalu cuo } \\ \text { whistle }=\& & \text { strike.CVant } & \text { (R) hat } & \text { give.back } & \text { 3s.ERG }\end{array}$

'He whistles to him and gives back the hat.'

(3) Oblique object as host:

$\begin{array}{lllll}\text { molla-n } & \text { nawar-aga='a } & \text { vaxaa } & \text { axcha hwa-diixaad cuo } \\ \text { mullah-GEN } & \text { door-all }=\& & \text { V.go.CVant } & \text { money here-D.ask. nw.D } & \text { 3s.ERG }\end{array}$

'...he went to the mullah's house and asked for his money back.' (GhF)

(4) Deictic and spatial preverb as host:
Dehwa Hwuliera viraa
$t^{\prime} y=$ 'a byllie $\quad h w a={ }^{\prime} a$ bei
(place name)-ABL donkey-DAT on=\&-B.put.CVseq here=\&-B.bring.CVseq
yz k'ei toppar c'agha dwatuoxar
DEM white clay home DX-strike.IMPF

They would load white clay from Outer Hwulii, pack it out with a donkey, and whitewash houses with it. (0392B) 
(5) Negative proclitic as host:

$\begin{array}{llllll}\text { Muusaa-z } & \text { hwal } & c y={ }^{\prime} a & \text { ghott-azh, } & \text { ghealie } & \text { iiz-ar } \\ \text { Musa-ERG } & \text { up } & N E G=\& & \text { stand-CVsim } & \text { cigarette } & \text { smoke- WP }\end{array}$

'Musa smoked a cigarette without getting up.'

(6) Reduplication in absence of a host:

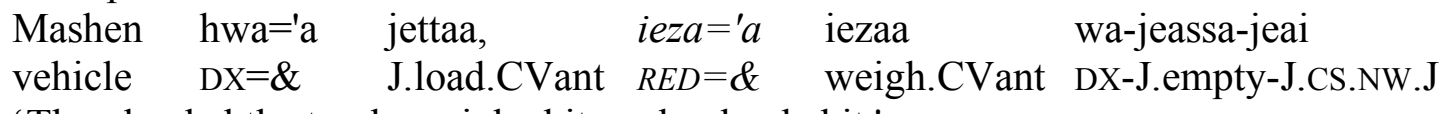

'They loaded the truck, weighed it, and unloaded it.'

So far this has remained the best and only firm example of a Type 5 clitic. We found that an identical construction, with a functionally identical (but not cognate) clitic, occurs in all the Andic languages (Nakh-Daghestanian: Daghestanian branch, Avar-Andic-Tsezic subbranch; adjacent to Chechen). In Godoberi core serialization "one of the NP's (normally the nominative NP) is marked with the particle - $l a "$ "Kibrik 2005:198) and similarly for Bagwalal. We reviewed all examples of chaining and all texts in both grammars, and find that the construction uses the same basic converbs and has the same conjunct categories and obligatory argument sharing as in Chechen and Ingush, and the clitic is a Type 5 clitic enclitic on the direct object if one is present, otherwise a preverb, otherwise a reduplicate; the main clause is often verb-initial. Bagwalal examples are (7)-(12) (Kibrik 2001).

(13) Absolutive P as host:

o-b ahan=la b-ij-ē-b-o hunssa-ri č'ihi k'anc'ur-u-ba this=B event $=\& \quad$ B-know-CAUs-B-CV Xushtadin-pl on.top jump-PART-HPL The Xushtada people found out about this event and attacked (us). (2.10)

(14) First element of bipartite stem as host:

$\begin{array}{lll}\ldots . .0-\text {-ru-r } & k u m u k=l a & \text { ǰē-b-o } \\ \text { to-B-CV } & \\ \text { this-OBL.HPL-ERG } & \text { help=\& } \\ \text { mašina } & \text { b-iR-ēb-o ek 'a } \\ \text { car } & \text { B-stand-CAUS-B-CV }\end{array}$

'...with their help (=they helping), they got the car upright.' (8.7)

(15) Oblique object as host:

$\begin{array}{lll}\text { hē } & \text { kamandirowačni-tti-X=la } & \text { W-ič' } ̃ \text {-w-o } \\ \text { then } & \text { pass- } O B L-A D=\& & \text { W-look-W-CV }\end{array}$

hežāa-Rala $\quad \mathrm{k}_{\mathrm{o}}$ at'ir-ō-w-di heL'i

why-RALA late.IPF-PART-W-DI say

'He looked at my pass and asked, "Why are you late?"'(8.78)

(16) Absolutive S as host:

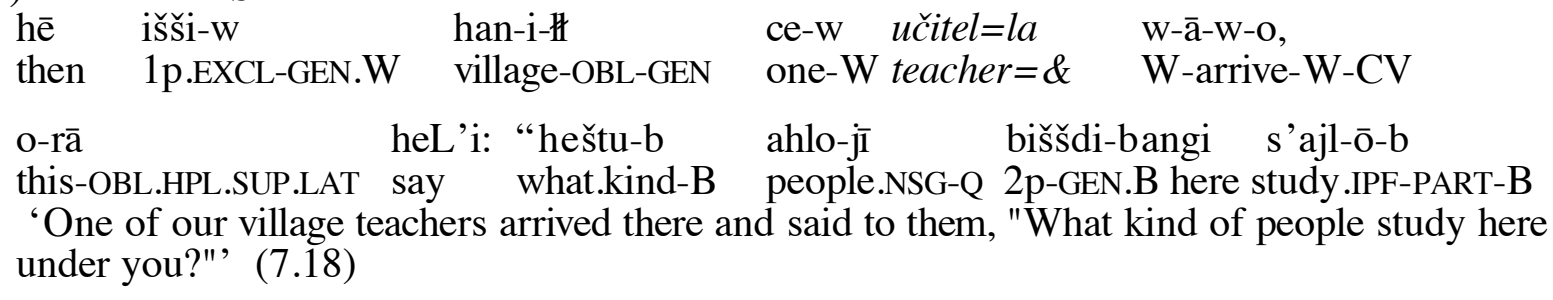

(17) Spatial adverbial as host: 
$\begin{array}{lllll}\text { hē } & \text { den heL'i } & \text { oššs-a: } & \text { "dē } & \text { w-eł-a-ss-Re } \\ \text { then } & \text { 1s.ERG say } & \text { this-OBL.M.SUP.LAT } & \text { 1s } & \text { M-go-MS.POT-FUT1-REupwards }\end{array}$

čihi-la w-ełi-w-o, ...

upwards-\& M-go-M-CV

'Then I said to him, "I'll climb up, and having climbed up..." ' (8.57)

(18) Reduplication in absence of a host:

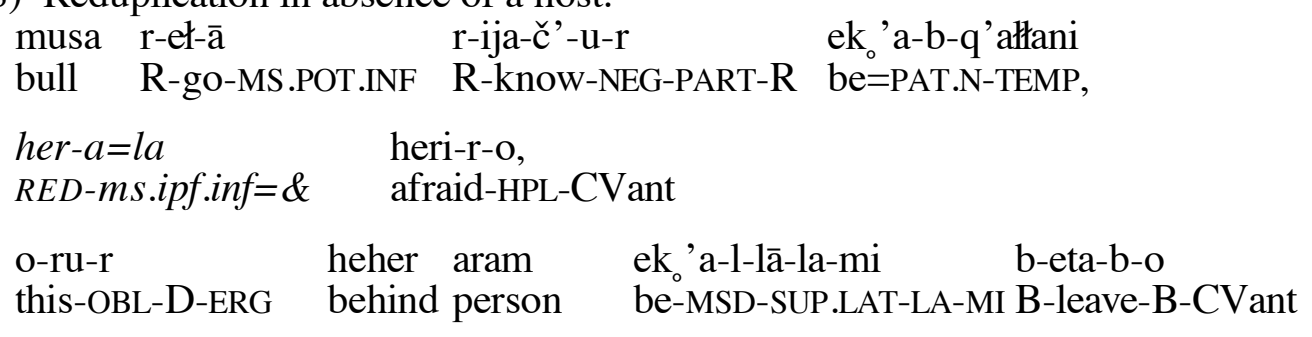

...o-ba r-uk'a-da-ła he-b- agila=la r-eta-r-o,

this-B R-be-DA-LOC what-B-UQ=\& R-leave-R-CVant

han-łi b-ełi-r-o ek'a

village-INTER B-go.out-HPL-CVant be

'When the bulls lost the ability to walk, they (three people from Xushtada) became afraid, and thinking that behind there were people (from Kvanada), leaving them behind right where they were, they went off to their own village.' (2.25)

Avar is adjacent and a close sister to the Andic languages, and standard Avar (Bokarev 1949:220-221, Alekseev \& Ataev 1998, Uslar 1889) has a pattern very similar to ChechenIngush and Andic; the clitic is $=g i$. For other nearby sister languages we found less consistency with the Nakh-Andic pattern. In southern Avar (Chadakolob, Antsukh dialect) (Kibrik 1981:141.20.46-47), whether with same or different subject, and even with overt arguments in the clause, in these elicited examples the anterior converb is always reduplicated.

Tsezic subbranch of Avar-Andic-Tsezic: Clitic =no 'and' can occur on one or another word in a converb or main clause; often on more than one word per clause; in different-subject (non-coreferential) clauses as well as same-subject clauses. Probably no reduplication. (Based on quick survey of Kibrik 1979-81, van den Berg 1995)

Lak (isolate branch of Daghestanian): The clitic $=g u$ 'and' has similar functions (V. Friedman, p.c.).; examples surveyed suggest few or no constraints on host. No reduplication examples found. The clitic is nearly identical to Avar and a likely loan.

Geographically more distant sisters generally have converb chaining but but not specifically core chaining (no conjunct categories, no obligatory sharing), and they have no chaining clitic and no reduplication in chaining (e.g. Ic'ari Dargi: Sumbatova \& Mutalov 2003:176, 187-8). Unrelated neighboring languages (e.g. Georgian [Kartvelian], Ossetic [Iranian], Kabardian [West Caucasian] have little or no core chaining and nothing analogous to the clitic. In the entire Caucasus, verb + subject order in chain-final clauses is apparently unique to Chechen, Ingush, Avar, and Andic core chaining (survey underway at this writing).

A clitic type this rare, this heavily constrained, and packaged with a rare word order should hardly be a good candidate for diffusion, but it must have diffused among these languages. The likely source is Avar, which has been the local lingua franca for some centuries. But while Tsezic languages have yielded to Avar more than Andic languages have, Avar and 
Andic have near-identical Type 5 clitic behavior while Tsezic is different and less consistent; and Ingush, which has had little or no direct Avar influence, nonetheless has a near-clone of the Avar-Andic construction, perhaps spread via its close sister Chechen, which has direct Avar contact. An Andic or Andic-like substratum is possible for the eastern Chechen highlands, and this is another possible source of contact. Batsbi, a close sister of Chechen and Ingush, is spoken on the south Caucasus slope, out of Avar-Andic contact, and appears to lack the clitic and reduplication entirely. Overall, the geography of the diffusion partly follows but mostly crosscuts the usual uphill spread pattern of the Caucasus (Volkova 1967, Wixman 1980, Nichols 2005).

The clitic is easily calqued and of high frequency, so it spreads more readily than the reduplication, which is less frequent and less stable. Both spread easily among languages with coreferential, case-sensitive narrative chaining (Avar, Andic, Chechen, Ingush), but apparently Tsezic chaining is of a different type.

The coordinating particle is an ordinary enclitic in all the languages. Only in its chaining function is it strictly Type 5, and in this position it is highly consistent where it has diffused. This suggests that Type 5 clitics are not cross-linguistically disfavored.

\section{References}

Alekseev, M. E. and B. M. Ataev. 1998. Avarskij jazyk. Moscow: Academia.

Bickel, Balthasar. In press. Capturing particulars and universals in clause linkage: a multivariate analysis. In Bril, I. (ed.) Clause hierarchy and clause linking: The syntax and pragmatics interface. Amsterdam: Benjamins.

Bokarev, A. A. 1949. Sintaksis avarskogo jazyka. Moscow: AN.

Conathan, Lisa and Jeff Good. 2000. Morphosyntactic reduplication in Chechen and Ingush. CLS 36.49-61.

Crowley, Terry. 2002. Serial Verbs in Oceanic: A Descriptive Typology. Oxford: Oxford University Press.

Kibrik Aleksandr E. 1979-1981. Materialy k tipologii ergativnosti. (Predvaritel'nye publikacii, 126-141.) Moscow: Russian Language Institute, AN SSSR.

Kibrik, Aleksandr E., ed. 2001. Bagvalinskij jazyk. Moscow: IMLI RAN "Nasledie".

Kibrik, Aleksandr E., ed. (1996) 2005. Godoberi. Munich: Lincom.

Klavans, Judith. 1875. The independence of syntax and phonology in cliticization. Language 61.95-120.

Nichols, Johanna. 2005. The origin of the Chechen and Ingush: A study in alpine linguistic and ethnic geography. Anthropological Linguistics 46.129-155.

----. Forthcoming. Ingush Grammar. University of California Publications in Linguistics.

Peterson, David A. 2001. Ingush 'a: The elusive Type 5 clitic? Language 77.144-155.

Uslar, P. K. 1889. Avarskij jazyk. (Etnografija Kavkaza: Jazykoznanie, 3.) Tbilisi: Kavkazskij Uchebnyj Okrug.

van den Berg, Helma. 1995. A Grammar of Hunzib (with Texts and Lexicon). MunichNewcastle: Lincom Europa.

Volkova, N. G. 1967. Voprosy dvujazychija na Severnom Kavkaze. Sovetskaja ètnografija 1967:1.27-40.

Wixman, Ronald. 1980. Language Aspects of Ethnic Patterns and Processes in the North Caucasus. University of Chicago Department of Geography Research Paper 191. 